\title{
КРИМІНАЛІСТИЧНА ХАРАКТЕРИСТИКА НАСИЛЬСТВА В СІМ'Ї
}

Кравцова М. О.

\begin{abstract}
Сімейно-побутове насильство займає значне місце $e$ структурі насильницької злочинності. Воно, як кримінологічна проблема, містить нескінченне різноманіття суперечливих ситуацій економічного, політичного, правового, методологічного, світоглядного, психологічного, медичного та іншого характеру. У роботі розглянуто поняття та ознаки сімейного насильства згідно з чинним Законодавством України. Визначено основні види та форми сімейного насильства. Досліджені причини, які спонукають до сімейного насильства та основні заходи з попередження сімейного насильства в Україні.
\end{abstract}

Ключові слова: сімейне насильство, гендерна нерівність, фізичне насильство, психологічне насильство.

Семейно-бытовое насилие занимает значительное место в структуре насильственной преступности. Оно, как криминологическая проблема, содержит бесконечное многообразие противоречивых ситуачий экономического, политического, правового, методологического, мировоззренческого, психологического, медичинского и иного характера. В работе рассмотрены понятия и признаки семейного насилия согласно действующему Законодательству Украины. Определены основные виды и формы семейного насилия. Исследованы причины, побуждающие к семейному насилию и основные мероприятия по предупреждению семейного насилия в Украине.

Ключевые слова: семейное насилие, гендерное неравенство, физическое насилие, психологическое насилие.

Domestic violence has a significant place in the structure of violent crime. In family conflicts, it is expressed in terms of harming the health of varying degrees of severity or death. It should be acknowledged that at present the level of knowledge about the nature of domestic violence is insufficient, which necessitates the need to conduct comprehensive (with a systematic approach) social-psychological, criminological and medical-psychiatric research in this field, devoted to both practical and theoretical issues.

Theoretical research should be directed to the systematic study of the factors that cause family and domestic conflicts and cause them to grow into different variants of criminal behavior. The application side should be responsible for developing a system of preventative measures designed to eliminate or counteract the criminogenic factors that trigger domestic violence.

Domestic violence, as a criminological problem, contains an endless variety of contradictory situations of economic, political, legal, methodological, ideological, psychological, medical, pedagogical and other nature. These circumstances form the idea of analysis and systematization of knowledge about nature, mechanisms of formation and functioning, neutralization of domestic violence, and in the final form - the development of criminological theory of domestic violence.

Domestic or domestic violence is one of the forms of ill-treatment of children and partners, including those who are not married. Domestic violence, although contrary to the norms and values of a civilized society, is a widespread problem in many countries, including European countries.

Кравцова М. О., 2019
The article deals with the concepts and features of domestic violence under the current legislation of Ukraine. The main types and forms of domestic violence are identified. The causes of domestic violence and the main measures to prevent domestic violence in Ukraine have been investigated.

Key words: domestic violence, gender inequality, physical violence, psychological violence.

Постановка проблеми та іï актуальність. На даний час у нашому суспільстві гостро стоїть питання домашнього насильства, перед яким особливо безсилі неповнолітні діти та жінки. Незважаючи на намагання суспільства та держави боротися з цією проблемою, залишається багато факторів, які сприяють домашньому насильству, такі як недосконалість та неоднозначність Законодавства, гендерні стереотипи та низький рівень обізнаності потерпілих про свої права.

Теоретичні дослідження питання насильства в сім"ї повинні бути спрямовані на системне вивчення чинників, які породжують сімейні та побутові конфлікти й обумовлюють їх переростання в різні варіанти злочинної поведінки.

Актуальним залишається розробка системи ефективних превентивних заходів, покликаних ліквідувати або нейтралізувати дію криміногенних факторів, що породжують насильство в сім'ї.

Аналіз останніх досліджень. Теоретичні аспекти насильницьких злочинів у сім'ї досліджувались в працях С.М. Абельцева, Ю.М. Антоняна, О.М. Бандурки, А.В. Запорожцева, А.В. Лабунь, Д.Г. Заброда, І.В. Басиста, І.В. Дроздова, В.О. Брижика, О.М. Мусі-

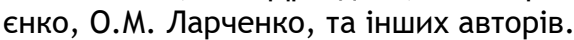

Метою статті $\epsilon$ надання кримінологічної характеристики явища насильства в сім'ї та дослідження шляхів запобігання та протидії домашньому насильству.

Виклад основного матеріалу. Основним безпосереднім об'єктом будь-якого насильницького злочину $\epsilon$ суспільні відносини, що забезпечують життя, здоров'я або тілесну недоторканість особи. Посягання на гідність, свободу чи інші блага особи без безпосереднього впливу на організм людини або загрози такого впливу не $\epsilon$ насильством [8, ст. 2].

Суть сімейного насильства полягає в порушенні, насамперед, особистих прав i свобод конкретної людини, які закріплені в Конституції України.

Часто під час того, як відбувається сімейне насильство, $\epsilon$ неможливим самозахист, оскільки одна сторона має переваги над іншою. Коли існує будь-який із видів переваг (фізична, матеріальна, інтелектуальна емоційна), які використовуються проти іншого члена сім'ї, $\epsilon$ насильством у сім'ї.

Кримінологи сім'ю розглядають як соціальний інститут, у якому здійснюються найважливіші етапи формування особистості, а також як середовище із власними традиціями та звичками, що можуть формувати причини і умови злочинної поведінки [1]. 
Діяння можна назвати насильством у сім'ї за умови, що воно порушує вимоги чинного законодавства та призводить чи може призводити до порушення конституційних прав і свобод члена сім'ї. Насильство в сім'ї поділяють на активне та пасивне. Активні дії - це нанесення побоїв, знищення майна тощо. Насильство може мати також форму бездіяльності, тобто пасивної поведінки особи, коли вона не вчиняє дій, які могла та повинна була вчинити, щоб запобігти настанню шкідливих наслідків.

Згідно із Законом України «Про попередження насильства в сім'і» виділяють такі обов'язкові ознаки насильства в сім'ї [5]:

1) особами, які страждають від сімейного насильства, можуть бути тільки члени сім'і;

2) діяння кривдника повинно бути протиправним;

3) діяння призвело або могло призвести до порушення прав члена сім'ї як людини, так і громадянина;

4) вина кривдника повинна виявлятися у формі умислу, а не необережності.

Згідно з Законом України «Про запобігання та протидію домашньому насильству», прийнятим у 2017 році, до Кримінального кодексу України була введена стаття ст. 126-1 Кримінального кодексу України про домашнє насильство. Ця стаття встановлює кримінальну відповідальність за умисне систематичне вчинення фізичного, психологічного або економічного насильства [2; 6].

Ознакою насильства в сім'ї $\epsilon$ наявність моральної, фізичної або психічної шкоди здоров'ю члена сім'ї, що заподіяна внаслідок протиправних діянь.

Насильство в сім'ї - це будь-які умисні дії фізичного, сексуального, психологічного чи економічного спрямування одного члена сім'ї по відношенню до іншого члена сім'ї, якщо ці дії порушують конституційні права і свободи члена сім'ї, як людини та громадянина, і наносять йому моральну шкоду, шкоду його фізичному чи психічному здоров'ю.

Види насильства в сім'ї :

- фізичне насильство в сім'ї - умисне нанесення одним членом сім'ї іншому члену сім'ї побоїв, тілесних ушкоджень, що може призвести або призвело до смерті постраждалого, порушення фізичного чи психічного здоров'я, нанесення шкоди його честі й гідності;

- сексуальне насильство в сім'ї - протиправне посягання одного члена сім'ї на статеву недоторканість іншого члена сім'ї, а також дії сексуального характеру по відношенню до неповнолітнього члена сім'ї;

психологічне насильство в сім'ї - насильство, пов'язане з дією одного члена сім'ї на психіку іншого члена сім'ї шляхом словесних образ або погроз, переслідування, залякування, якими навмисно спричиняється емоційна невпевненість, нездатність захистити себе та може завдаватися або завдається шкода психічному здоров'ю;

- економічне насильство в сім'ї - умисне позбавлення одним членом сім'ї іншого члена сім'ї житла, їжі, одягу та іншого майна чи коштів, на які постраждалий має передбачене законом право, що може призвести до його смерті, викликати порушення фізичного чи психічного здоров'я» [2].

Існують такі прояви фізичного насильства в сім'ї:

- загроза зброєю;

- удушення;

- побиття, стусани та укуси;
- заподіяння опіків;

кидання предметами в бік жертви;

відмова надати необхідну допомогу в разі хвороби або вагітності.

Фізичним насильством у сім'ї можуть порушуватись особисті права, такі як право на вільний розвиток своєї особистості, право на життя, свободу та особисту недоторканість.

Фізичне насильство вважається одним із найтяжчих видів насильства в сім’ї тому, що дії кривдника посягають безпосередньо на життя і здоров'я, недоторканість та безпеку особи, які, згідно зі ст. 3 Конституції України, визнаються найвищою соціальною цінністю [1].

Різновидом фізичного насильства $\epsilon$ сексуальне насильство. Сексуальне насильство в сім'ї - протиправне посягання одного члена сім'ї на статеву недоторканість іншого члена сім'ї, а також дії сексуального характеру стосовно неповнолітнього члена сім'ї. Сексуальне насильство в сім'ї може порушувати такі права і свободи особи, як право на повагу гідності, право на особисту недоторканність, право на вільний розвиток своєї особистості тощо.

Більшість видів сексуального насильства закріплені у Кримінальному кодексі України, тобто визнаються злочинами. Зокрема, це [2]:

- примус жінки до сексуальних зносин із чоловіком та іншими людьми проти їі волі;

- примус до болісних або садистських статевих зносин та застосування предметів для цієї мети;

- применшення значення почуттів партнера в сексуальному відношенні;

- застосування погрози насильством для примусу партнера (найчастіше жінки) до згоди на сексуальний зв'язок;

- демонстрація дитині (підлітку) статевих органів (ексгібіціонізм);

- демонстрація акту онанізму;

- залучення до заняття дитячою проституцією, у тому числі використовуючи порнографічну літературу, фотографії, кінофільми та ін. з метою одержання прибутку.

Сексуальне насильство в сім'ї може виявлятися не тільки у вигляді злочинів, а й у сексуальній поведінці, яка не суперечить Кримінальному Кодексу України, і все ж, відповідно до Закону про попередження насильства, порушує сексуальну недоторканість і статеву свободу жінки чи чоловіка [2; 5].

Психологічне насильство в сім'ї може порушувати такі права, як право на рівність у гідності та правах, право на повагу гідності, таємницю листування, телефонних розмов, кореспонденції, право на свободу думки і слова тощо [1].

Психологічне насильство в сім'ї може мати різні прояви: образи з використанням лайливих слів та (або) криків, образливі жести, пози, міміка, погляди, інтонації, тримання членів сім'ї в атмосфері страху. Психологічне насильство виявляється у брутальному ставленні до родичів чи друзів члена сім'ї, заподіянні шкоди домашнім тваринам, знищенні, пошкодженні, псуванні або приховуванні особистих речей, предметів, прикрас тощо, використанні принизливих зауважень щодо члена сім'ї, постійних проявах незадоволення, безпідставних докорів, зауважень і звинувачень, крайніх проявах підозрілості, ревнощів, перевірок, стеження, що робить нестерпним життя тощо. 
Також проявами психологічного насильства можуть бути: ігнорування почуттів особи; образа переконань, що мають цінність для особи; образа віросповідання, національної, расової та класової приналежності або походження; переслідування особи (частіше жінки чи дівчини) через уявлені особою протилежної статі сексуальні зв'язки; обмеження свободи дій та пересування особи; погрози заподіяти фізичну чи економічну шкоду; погрози залишити сім'ю, побити чи вбити дружину, дітей; підштовхування до самогубства; примушення до протизаконних дій; ізоляція від оточуючих; використання дітей проти матері; залякування, усунення від процесу ухвалення рішень; заперечення наявності проблеми насильства, перекладання відповідальності за неї на партнера; обмеження в самореалізації, навчанні, роботі.

Найбільш гостро проблема психологічного насильства в сім'ї постає серед дітей, оскільки вони $\epsilon$ вразливими та необізнаними. Вразливість дітей до насильства пояснюється їхньою фізичною, психологічною та соціальною незрілістю, а також залежним становищем стосовно дорослих (батьків чи опікунів).

Економічне насильство в сім'ї буває різних видів у вигляді економічного тиску на члена сім'ї, а також різні види позбавлення або обмеження трудових і майнових прав. Такими видами насильства можуть бути заборона працювати члену сім'ї за наявності його бажання та працездатності; позбавлення або обмеження одним членом сім'ї іншого члена сім'ї можливості користуватися й розпоряджатися грошима, які він заробив або які $\epsilon$ їхньою спільною власністю; примус члена сім'ї виконувати важку, непосильну роботу; відмова члена сім'ї опікуватися малолітніми, неповнолітніми членами сім'ї, старими, інвалідами тощо. Економічне насильство може виявлятись у створенні ситуації, за якої один член сім'ї змушений систематично просити гроші, коли вони в сім'ї $\epsilon$, на утримання сім'ї або на власні потреби, у втягненні неповнолітніх у заняття жебрацтвом, пошкодженні чи знищенні майна іншого члена сім’ї або спільного майна, примушуванні чи втягненні в заняття проституцією. За окремі, найбільш небезпечні види економічного насильства в сім'ї передбачена кримінальна відповідальність [9, ст. 19].

Найчастіше акт домашнього насильства включає в себе різноманітні комбінації грубої фізичної та сексуальної поведінки у вигляді психологічних та економічних зловживань. Насильство в сім'ї може розглядатися за такими напрями [9]:

1. Подружжя. Здебільшого насильство здійснюється чоловіком, хоча зустрічаються і протилежні випадки.

2. Батьки та їх неповнолітні діти. Насильство може здійснюватись як обома батьками, так і одним із них.

3. Дорослі діти та їх батьки. Насильство може здійснюватись як дорослими дітьми стосовно батьків, так і навпаки, хоча перший випадок значно поширеніший.

4. Насильство між дітьми.

5. Член сім'ї - інші родичі (між тещею чи тестем і зятем, свекром чи свекрухою і невісткою, онуками і дідусем чи бабусею).

6. Насильство проти хворих, немічних членів сім’ї, членів сім'ї - інвалідів.

Причини застосування насильства в сім'ї умовно можна поділити на такі групи [9, ст. 25]:
- соціальні (напруження, конфлікти, насильство в суспільстві, пропагування в засобах масової інформації насильства як моделі поведінки);

економічні (матеріальні нестатки, відсутність гідних умов життя поряд із відсутністю умов для працевлаштування, заробляння грошей, економічна залежність, безробіття);

психологічні (стереотипи поведінки);

педагогічні (відсутність культури поведінки - правової, моральної, громадянської, естетичної, економічної, трудової);

соціально-педагогічні (відсутність усвідомленого батьківства, сімейних цінностей у суспільстві, позитивної моделі сімейного життя на засадах гендерної рівності, сімейного виховання на основі прав дитини);

правові (ставлення до насильства як до внутрішньосімейної проблеми, а не як до негативного суспільного явища, до членів сім'ї як до власності через відсутність правової свідомості);

політичні (прихильність до гендерних стереотипів, недостатній пріоритет проблем сім'ї та гендерної рівності, увага до материнства і дитинства, а не сім'ї в цілому, брак уваги до батьківства, чоловіків);

соціально-медичні (відсутність репродуктивної культури у населення, відповідального батьківства, системи сімейних лікарів, алкоголізм, наркоманія, агресія тощо);

фізіологічні та медичні (порушення гормонального фону, обміну речовин, швидкості реакцій, прийом збуджувальних ліків, хвороби нервової системи тощо).

Гендерні стереотипи відіграють істотну роль у поширенні насильства в сім'ї, насамперед над жінками. Під впливом цих стереотипів, як правило, перебувають насильники-чоловіки, часто жертви насильства та особи, які їх оточують, а іноді й працівники поліції, які за своїм посадовими обов' язками мають втручатись у випадки насильства в сім'ї [9, ст.24].

Головною складовою попередження сімейного насильства $\epsilon$ подолання гендерних стереотипів у суспільстві взагалі та в осіб, які працюють у сфері боротьби з цим явищем. Тому на рівні держави необхідно докладати постійних зусиль до подолання гендерних стереотипів у суспільстві.

До насильства в сім'ї призводять певні соціальні та культурні умови, якими можуть бути [1, 5, 9, ст.25]:

відсутність у соціальній свідомості чіткої оцінки фізичних покарань; мації;

демонстрація насильства в засобах масової інфор-

права громадян на недоторканість приватного життя, власну та сімейну таємницю, закріплені у Конституції, не дозволяють своєчасно встановити факт насильства і здійснити втручання;

відсутність ефективної превентивної політики держави

- недостатнє розуміння суспільством насильства як соціальної проблеми;

низька правова грамотність населення;

- погана обізнаність дорослих і дітей про свої права;

- недосконалість чинного законодавства.

Згідно зі ст. 24 Закону України «Про забезпечення рівних прав та можливостей жінок і чоловіків» та ст. 15 Закону України «Про попередження насильства в сім'ї» особи, винні в порушенні вимог законодавства 
про забезпечення рівних прав та можливостей жінок ічоловіків, а так само члени сім'ї, які вчинили насильство в сім'ї, несуть кримінальну, адміністративну чи цивільно-правову відповідальність відповідно до закону [5; 7].

У Законодавстві України передбачено спеціальні заходи з попередження насильства в сім'ї, до яких відносяться [5; 7]:

- офіційне попередження про неприпустимість вчинення насильства в сім'ї;

- взяття на профілактичний облік членів сім'ї, які вчинили насильство в сім'і;

- встановлення захисного припису;

стягнення коштів на утримання жертв насильства в сім'ї у спеціалізованих установах для жертв насильства в сім'ї.

Кодекс України про адміністративні правопорушення передбачає відповідальність за вчинення насильства в сім'ї, невиконання захисного припису або непроходження корекційної програми. При цьому верхня межа санкцій відповідних статей Кодексу передбачає адміністративне стягнення у вигляді адміністративного арешту на строк до п'ятнадцяти діб, що $\epsilon$ винятковим і досить суворим заходом адміністративного впливу на правопорушника [3].

Захисний припис $є$ спеціальним заходом, який має на меті, насамперед, захистити потерпілу особу та унеможливити повторення насильства, що однак не передбачає заборони для особи, яка вчинила насильство в сім'ї, перебувати в одному приміщенні з жертвою насильства в сім'ї. Отже, у разі спільного їх проживання захисний припис не змінює ситуації й не може вважатися ефективним засобом захисту потерпілих від насильства в сім'ї та недопущення повторного насильства [3; 9, с. 62].

Сімейний кодекс України спрямований на подальше зміцнення сім'ї та визначає сферу сімейних і родинних відносин, які підлягають правовому регулюванню, межі правового впливу на них (ст. 2), закріплює принцип рівноправності громадян у сімейних стосунках (ст. 54), а також передбачає право дружини та чоловіка на свободу та особисту недоторканість (ст. 56). Ним передбачені відповідні правові гарантії щодо охорони й захисту прав та інтересів сім'ї, регулюється порядок вирішення спорів між подружжям, батьками й дітьми, іншими членами родини, а також визначені правові наслідки щодо недотримання ними своїх обов'язків [4].

Аналіз чинного кримінального законодавства України дозволяє визначити кримінально-правові норми, які встановлюють відповідальність за насильницькі злочини, в тому числі у сфері сімейних відносин. Ці статті розташовані в різних розділах Особливої частини Кримінального Кодексу України, зокрема: ст. 115 «Умисне вбивство», ст. 116 «Умисне вбивство, вчинене у стані сильного душевного хвилювання», ст. 117 «Умисне вбивство матір'ю своєї новонародженої дитини», ст. 120 «Доведення до самогубства», ст. 121 «Умисне тяжке тілесне ушкодження», ст. 122 «Умисне середньої тяжкості тілесне ушкодження», ст. 123 «Умисне тяжке тілесне ушкодження, заподіяне у стані сильного душевного хвилювання», ст. 125 «Умисне легке тілесне ушкодження», ст. 126 «Побої і мордування», ст. 127 «Катування», ст. 129 «Погроза вбивством»у розділі ІІ «Злочини проти життя та здоров'я особи»; ст. 152 «Зґвалтування», ст. 153 «Насильницьке задоволення статевої пристрасті неприродним способом», ст. 154 «Примушування до вступу в статевий зв'язок»у розділі IV «Злочини проти статевої свободи та статевої недоторканості особи» [4].

Висновки. Отже, необхідно зазначити, що криміналізація домашнього насильства в Україні $€$ важливим та необхідним нововведенням, оскільки ці норми передбачають відповідальність за сімейне насилля. Визнання сімейного насилля злочином забезпечить у майбутньому зниження цього виду насильства шляхом застосування превентивних та обмежувальних заходів щодо винних у домашньому насильстві осіб, викорінення економічного тиску у відносинах між партнерами, захист дітей, постраждалих від таких злочинів.

\section{Література}

1. Конституція України від 28.06.1996 р. із змінами i доповненнями № 1-рп / 2016 від 15.03.2016 р.

2. Кримінальний кодекс України: чинне законодавство із змінами і доповненнями 2475-VIII від 28.08.2018 p.

3. Кодекс України про адміністративні правопорушення № 102-11 від 12.04.85 р. із змінами та доповненнями № 2505-VIII від 12.07.2018 р.

4. Сімейний кодекс України № 407-IV від 26.12.2002 із змінами та доповненнями № 2475-VIII від 03.07.2018 p.

5. Закон України «Про попередження насильства в сім'”̈» № 2789 від 15.11.2001 р. із змінами та доповненнями (втратив чинність 07.01.2018р.).

6. Закон України «Про запобігання та протидію домашньому насильству» № 2229-VIII від 07.12.2017 p.

7. Закону України «Про забезпечення рівних прав та можливостей жінок і чоловіків» N 4719-VI від 17.05.2012 р. із змінами та доповненнями N 2229-VIII від 07.01.2018 p.

8. Ларченко О.М. Сімейні девіації як кримінологічна проблема / Кримінальне право і кримінологія Юридичний вісник № 3. 2011 p.

9. Насильство в сім'ї та діяльність органів внутрішніх справ щодо його подолання: навчально-методичний посібник для курсантів вищих навчальних закладів МBC України / Укладачі: Запорожцев А.В., Лабунь А.В., Заброда Д.Г., Басиста І.В., Дроздова І.В., Брижик В.О., Мусієнко О.М. Київ, 2012. 246 с.

Кравцова М. О., orcid.org/0000-0003-3704-5774 викладач кафедри загально-правових дисциплін Донецького юридичного інституту міністерства внутрішніх справ України 